\title{
Infeksi Cacing Usus pada Anak Sekolah Dasar Negeri Cilincing 06 Jakarta Utara Sebelum dan Sesudah Pengobatan Albendazol Dosis Tunggal
}

\author{
Rizqi Putra Pratama1, Monica Puspa Sari ${ }^{2}$, Esther Sri Majawati² \\ ${ }^{1}$ Fakultas Kedokteran dan Ilmu Kesehatan Universitas Kristen Krida Wacana, Jakarta, Indonesia \\ ${ }^{2}$ Departmen Parasitologi Fakultas Kedokteran dan Ilmu Kesehatan \\ Universitas Kristen Krida Wacana, Jakarta, Indonesia \\ Alamat Korespondensi: rizqi.2016fk022@ civitas.ukrida.ac.id
}

\begin{abstract}
Abstrak
Penyakit cacingan masih sering dijumpai di Indonesia. Seseorang lebih mudah terinfeksi cacing usus pada usia sekolah daripada usia dewasa. Penelitian ini bertujuan untuk melihat efektivitas obat Albendazol $400 \mathrm{mg}$ dosis tunggal terhadap infeksi cacing usus pada anak yang positif terinfeksi cacing usus di Sekolah Dasar Negeri Cilincing 06 Jakarta Utara. Pemeriksaan mikroskopis mengunakan metode Kato Katz dengan memakai tinja yang segar. Prinsip dari metode Kato Katz yaitu pemberian cellophane tape yang sudah direndam terlebih dahulu dengan malachite green selama 24 jam. Penelitian ini menggunakan metode eksperimental pre-post study. Pengambilan responden penelitian dengan metode simple random sampling dan analisis data menggunakan program IBM Statistical Product for Sosial Science (SPSS) versi 23.0. Kejadian infeksi cacing usus sebelum dilakukan pengobatan dari 82 siswa, terdapat 5 siswa $(6,1 \%)$ yang positif terinfeksi cacing usus dengan rincian Ascaris lumbricoides 3,7\%, Trichuris trichiura 2,4\%. Murid yang positif terinfeksi cacing usus diberikan pengobatan Albendazol $400 \mathrm{mg}$ dosis tunggal, didapatkan hasil sesudah pengobatan yaitu prevalensi untuk Ascaris lumbricoides $0 \%$, Trichuris trichiura 1,2\%. Analisis data secara statistik menggunakan uji Mc Nemar dan didapatkan hasil p value $>0,05$. Hasil uji statistik menunjukkan tidak terdapat perubahan yang signifikan dan bermakna dari hasil sebelum dan sesudah pengobatan Albendazol $400 \mathrm{mg}$ dosis tunggal.
\end{abstract}

Kata Kunci: albendazol, infeksi cacing usus, pengobatan

\section{Intestinal Helminth Infection in Children of Cilincing State Elementary School 06 North Jakarta before and after Treatment of Single Dose Albendazole}

\begin{abstract}
In Indonesia, the number of helminthiasis is still significant. A person is more easily infected with intestinal worms at school age than adult. This study aims to determine the effectiveness of a single dose of Albendazole $400 \mathrm{mg}$ against worm infections in children who were positive of intestinal worms. Subjects for this study were school children of Cilincing 06 Elementary School, North Jakarta. Microscopic examination was conducted using the Kato Katz method using fresh feces. This study uses an experimental pre-post study method. Respondents were selected based on a simple random sampling and data analysis was carried out using the IBM SPSS program version 23.0. Before treatment, out of 82 students, there were 5 students (6.1\%) who were positively infected with intestinal worms (Ascaris lumbricoides $3.7 \%$ and Trichuris trichiura $2.4 \%$ ). Students who were positive for intestinal worms were given a single dose of Albendazole $400 \mathrm{mg}$. Following this treatment, no infection of Ascaris lumbricoides was found (0\%), however Trichuris trichiura infection was still found (1.2\%). Statistical data analysis using Mc Nemar test obtained p value > 0.05. Statistical test results showed no significant change in the results before and after treatment of Albendazole 400mg single dose.
\end{abstract}

Keywords: albendazole, intestinal helminth infections, treatment 


\section{Pendahuluan}

Penyakit cacingan masih sering dijumpai di Indonesia. Penyakit ini kurang mendapat perhatian karena sering dianggap penyakit yang tidak menyebabkan kematian. ${ }^{1}$ Penyebab tingginya angka cacingan di Indonesia yaitu berkaitan dengan iklim dan kebersihan diri perorangan, rumah maupun lingkungan sekitarnya. Kepadatan penduduk yang tinggi, rumah yang berlantaikan tanah serta sanitasi yang buruk sangat terkait dengan prevalensi penyebab tingginya cacing usus di Indonesia. ${ }^{2,3}$ Daur hidup infeksi diawali dengan keluarnya telur cacing bersamaan dengan tinja manusia dan menjadi bentuk infektif ketika berada di tanah atau disebut juga soil-transmitted helminthes (STH). ${ }^{4}$ Jenis golongan $\mathrm{STH}$ ini di Indonesia paling banyak disebabkan oleh Ascaris lumbricoides, Trichuris trichiura, Necator americanus dan Ancylostoma duodenale. ${ }^{1}$

Menurut data dari World Health Organization (WHO) pada tahun 2015 lebih dari 1,5 miliar (24\%) populasi dunia yang terinfeksi cacing usus yang cara penularan melalui tanah STH. ${ }^{5}$ Menurut data WHO lebih dari 267 juta anak-anak yang belum memasuki usia sekolah dasar dan lebih dari 568 juta anak-anak yang memasuki usia sekolah dasar ditularkan secara intensif dan membutuhkan perawatan serta pencegahan. ${ }^{5}$ Prevalensi penyakit cacingan di Indonesia terbilang tinggi, dari survei yang dilakukan oleh Departemen Kesehatan Republik Indonesia di beberapa provinsi prevalensi angka cacingan pada semua umur berkisar antara $40 \%-60 \%$. $^{6}$

Menurut WHO, untuk memberantas infeksi cacingan obat yang digunakan adalah Albendazol $400 \mathrm{mg}$ dosis tunggal karena berspektrum luas sehingga dapat membunuh beberapa jenis cacing sekaligus. ${ }^{7}$ Berdasarkan penelitan yang dilakukan oleh Legese, dkk pada tahun 2002 mengenai keefektivitas albendazol 400mg dosis tunggal untuk pengobatan infeksi Ascaris lumbricoides dan Trichuris trichiura. Obat ditemukan sangat efektif terhadap infeksi Ascaris lumbricoides, dengan angka kesembuhan atau cure rate (CR) lebih dari 96\% dan pengurangan telur atau egg reduction rate (ERR) lebih dari 99,8\%. Keefektivitas obat terhadap infeksi Trichuris trichiura rendah yang menunjukkan CR dan ERR masing-masing 13,9\% dan $63,4 \%{ }^{8}$

Responden penelitian yang diambil adalah anak Sekolah Dasar Negeri Cilincing 06 Jakarta Utara alasan pemilihan sekolah di daerah tersebut adalah karena lingkungan yang padat, kumuh, banyak jajanan di sekitar sekolah yang kebersihannya masih diragukan, serta kebersihan dan sanitasi di sekitar sekolah yang terbilang kurang baik sehingga memungkinkan anak dapat terinfeksi cacing secara langsung. Berdasarkan survei yang dilakukan oleh Departemen Kesehatan Republik Indonesia pada tahun 2015 di wilayah kumuh di DKI Jakarta terutama di Jakarta Utara sendiri memiliki prevalensi yang cukup tinggi yaitu $37.5 \%$ dan didapatkan banyak terjadi pada anak usia sekolah dasar yang rentan terinfeksi cacingan. Menurut penelitian yang dilakukan oleh Merdiana dan Djarismawati pada pada murid SDWGT di Jakarta Utara pada tahun 2008 terdapat $80 \%$ positif menderita askariasis dan $20 \%$ positif menderita trikuriasis pada anak sekolah dasar. ${ }^{9}$

Infeksi cacing usus merupakan masalah yang serius dan harus segera ditangani. Pemerintah telah melakukan berbagai upaya untuk memberantas infeksi cacing usus melalui sekolah-sekolah. Oleh karena itu penelitian ini ingin melihat bagaimana kejadian cacingan pada salah satu sekolah di Jakarta Utara yaitu Sekolah Dasar Negeri Cilincing 06 Jakarta Utara sebelum dan sesudah dilakukan pemberian obat Albendazole $400 \mathrm{mg}$ dosis tunggal.

\section{Metodologi}

Penelitian ini telah dinyatakan lolos kaji etik oleh Komite Etik Penelitian Medis dan Kesehatan Fakultas Kedokteran Universitas Kristen Krida Wacana (UKRIDA) dengan nomor 786/SLKEIM/UKKW/FKIK/VIII/2019.

Penelitian ini menggunakan metode eksperimental pre-post study untuk menguji hipotesis dan membangun hubungan sebab-akibat atau hubungan antar variabel. ${ }^{10}$ Subjek penelitian ini adalah siswa kelas 3, 4, dan 5 Sekolah Dasar Negeri Cilincing 06 Jakarta Utara yang telah memenuhi kriteria inklusi dan eksklusi. ${ }^{10}$

Penelitian ini dilakukan di Sekolah Dasar Negeri Cilincing 06 Jakarta Utara pada anak kelas 3, 4 dan 5. Penelitian ini dimulai pada bulan Agustus 2019 dan langsung dilakukan pemeriksaan sampel di Laboratorium Departemen Parasitologi Fakultas Kedokteran Ukrida. Pemberian pengobatan terhadap siswa positif terinfeksi cacing usus dimulai pada periode Januari 2020 selama satu bulan masa pengobatan dan pemeriksaan sampel setelah pengobatan dilakukan pada bulan Febuari 2020.

Sampel tinja diperiksa dengan menggunakan metode Kato Katz, Prinsip pemeriksaan Kato Katz adalah penggunaan cellophane tape yang sebelumnya telah direndam dengan larutan malachite green selama 24 jam lalu preparat didiamkan selama 30 menit agar telur cacing menjadi transparan ketika dibaca di mikroskop. ${ }^{11,12}$ Penghitungan EPG (Egg per gram) tinja dilakukan dengan menghitung jumlah telur cacing yang 
diperoleh dari tinja seberat $41,7 \mathrm{mg}$ lalu hasilnya dikalikan $24 .{ }^{13}$

Cure rate (CR) diperoleh dengan cara menghitung jumlah pasien terinfeksi Soiltransmitted helminthes (STH) yang sembuh dibagi jumlah pasien yang diobati dikali $100 \%{ }^{18}$ Egg reduction rate (ERR) diperoleh dengan cara menghitung jumlah telur sebelum diobati dikurang jumlah telur setelah diobati dibagi rata-rata jumlah telur sebelum diobati dikali $100 \% .{ }^{18}$ Prevalensi infeksi STH sebelum dan sesudah pemberian pengobatan Albendazole dianalisis menggunakan uji Mc Nemar sedangkan ERR dianalisis dengan uji Wilcoxon signed rank test.

Analisis data menggunakan program IBM Statistical Product for Sosial Science (SPSS) versi 23.0. Analisis bivariat untuk menentukan hipotesis diterima atau tidak dengan menggunakan uji $M c$ Nemar untuk tingkat kesembuhan dan uji Wilcoxon signed rank test untuk jumlah telur. Kedua uji ini adalah sebagai alat statistik non parametrik yang digunakan untuk uji dua sampel berpasangan (pretest\&posttest) untuk mengetahui apakah hasil terdapat perbedaan bermakna atau tidak dengan melihat hasil $p$ value dengan tingkat kemaknaan $5 \%$ yaitu 0,05 .

\section{Hasil}

Terdapat 82 sampel yang dilakukan uji Kato Katz untuk mengidentifikasi telur cacing pada feses dan didapatkan 6 sampel murid yang positif terdapat telur cacing diantaranya 5 sampel terdapat telur cacing STH dan satu sampel terdapat telur cacing non STH. Oleh karena itu, pada penelitian ini terdapat total 5 sampel yang diberikan perlakuan berupa pengobatan Albendazole $400 \mathrm{mg}$ dosis tunggal sebagai terapi pada infeksi cacing usus STH lalu dicek 1 bulan kemudian.

\section{Tabel 1. Karakteristik Umum Responden Berdasarkan Jenis Kelamin, Usia dan Kelas}

\begin{tabular}{ccc}
\hline & $\begin{array}{c}\text { Seluruh } \\
\text { Responden } \\
\text { Penelitian }\end{array}$ & $\begin{array}{c}\text { Responden Penelitian } \\
\text { yang Terinfeksi }\end{array}$ \\
\hline Jenis kelamin & $\mathbf{N}(\%)$ & $\mathbf{N}(\%)$ \\
Laki-Laki & $44(53,7 \%)$ & $2(33,3 \%)$ \\
Perempuan & $38(46,3 \%)$ & $4(66,7 \%)$ \\
Total & $82(100 \%)$ & $6(100 \%)$ \\
Usia & & \\
8-10 Tahun & $48(58,5 \%)$ & $2(33,3 \%)$ \\
$11-13$ Tahun & $34(41,5 \%)$ & $4(66,7 \%)$ \\
Total & $82(100 \%)$ & $6(100 \%)$ \\
Kelas & & $1(16,7 \%)$ \\
3 SD & $25(30,5 \%)$ & $1(16,7 \%)$ \\
4 SD & $29(35,4 \%)$ & $4(66,7 \%)$ \\
5 SD & $28(34,1 \%)$ & $6(100 \%)$ \\
Total & $82(100 \%)$ & \\
\hline
\end{tabular}

Tabel 1 menunjukkan bahwa responden dengan jenis kelamin laki-laki ada sebanyak 44 $(53,7 \%)$. Sedangkan responden penelitian yang terinfeksi cacing usus berdasakan jenis kelamin laki-laki ada sebanyak $2(33,3 \%)$ dan jenis kelamin perempuan ada sebanyak $4(66,7 \%)$. Anak yang terinfeksi cacing lebih banyak yang kelas 5 SD (4 orang) daripada kelas 3 (1 orang) dan kelas 4 (1 orang).

Tabel 2. Prevalensi Infeksi Cacing Sebelum dan Sesudah Pengobatan

\begin{tabular}{|c|c|c|c|c|c|c|}
\hline \multirow[t]{3}{*}{ Pengobatan } & \multicolumn{4}{|c|}{ STH } & \multirow{2}{*}{\multicolumn{2}{|c|}{$\frac{\text { Non STH }}{\mathrm{EV}^{* * *}}$}} \\
\hline & \multicolumn{2}{|r|}{$\overline{\mathrm{AL}}$} & \multicolumn{2}{|r|}{ TT** } & & \\
\hline & + & - & + & - & + & - \\
\hline Sebelum & $3(3,7 \%)$ & $79(96,3 \%)$ & $2(2,4 \%)$ & $80(97,8 \%)$ & $1(1,2 \%)$ & $81(98,8 \%)$ \\
\hline Sesudah & 0 & $82(100 \%)$ & $1(1,2 \%)$ & $81(98,8 \%)$ & 0 & $82(100 \%)$ \\
\hline $\begin{array}{l}\text { P value } \\
\text { Mc Nemar }\end{array}$ & \multicolumn{2}{|r|}{0,5} & \multicolumn{2}{|r|}{1,0} & \multicolumn{2}{|c|}{1,0} \\
\hline Cure Rate (CR) & \multicolumn{2}{|r|}{$100 \%$} & \multicolumn{2}{|r|}{$50 \%$} & & \\
\hline $\begin{array}{c}\text { Egg Reduction Rate } \\
\text { (ERR) }\end{array}$ & \multicolumn{2}{|c|}{ Tidak Terinfeksi } & \multicolumn{2}{|r|}{1} & & \\
\hline
\end{tabular}

Ket: $\mathrm{AL}^{*}=$ Ascaris lumbricoides, $\mathrm{TT}^{* *}=$ Trichuris trichiura, $\mathrm{EV}^{* * *}=$ Enterobius vermicularis 
Berdasarkan jenis cacing yang ditemukan pada pemeriksaan feses didominanasi oleh cacing dengan golongan STHs yaitu sebanyak 5 sampel $(6,1 \%)$ yaitu Ascaris lumbricoides, Trichuris trichiura dengan total sampel berturut-turut yaitu 3 (3,7\%), 2 (2,4\%). Sedangkan Enterobius vermicularis yang termasuk golongan non STH didapatkan 1 responden $(1,2 \%)$ dari total sampel. Setelah terindentifikasi berapa banyak responden yang terinfeksi cacing, maka peneliti melakukan perlakuan berupa pengobatan albendazol $400 \mathrm{mg}$ dosis tunggal kepada setiap responden yang terinfeksi cacing dan satu bulan setelah pemberian terapi, didapatkan penurunan kejadian infeksi cacing Ascaris lumbricoides dan Enterobius vermicularis menjadi $0 \%$ sehingga dapat diartikan bahwa dari hasil pemeriksaan feses tidak ditemukan lagi telur cacing sehingga responden dapat dinyatakan sembuh dari infeksi cacing Ascaris lumbricoides dan Enterobius vermicularis. Namun, terdapat satu dari dua responden yang dinyatakan sembuh dari infeksi cacing Trichuris trichiura dikarenakan pada pemeriksaan feses masih didapatkan telur cacing pada satu responden.

Untuk melihat apakah penurunan prevalensi infeksi cacing usus bermakna atau tidak secara statistik, maka peneliti menggunakan uji $M c$ Nemar dan didapatkan hasil $\mathrm{p}$ value $>0,05$ maka Ho diterima yang berarti tidak terdapat perubahan yang signifikan dan bermakna dari hasil sebelum dan sesudah pengobatan Albendazole 400mg dosis tunggal dalam infeksi cacing usus.

Didapatkan hasil ERR Ascaris lumbricoides tidak dapat dihitung karena sudah tidak ditemukan lagi telur cacing sehingga didapatkan hasil CR yaitu $100 \%$ yang berarti terdapat kesembuhan total sampel yang terinfeksi cacing Ascaris lumbricoides sedangkan hasil ERR Trichuris trichiura yaitu $1(100 \%)$ sehingga didapatkan hasil CR yaitu 50\% dikarenakan satu dari dua sampel yang terinfeksi cacing Trichuris trichiura sembuh.

Semua tabel mohon diperbaiki 3garis horisontal saja, tidak terputus halaman, judul tabel di atas, keterangan tabel di bawah tidak terpisah halaman

Tabel 3. Jumlah Telur, EPG dan Intensitas Infeksi Cacing Sebelum dan Sesudah Pengobatan pada Pemeriksaan Kato Katz

\begin{tabular}{|c|c|c|c|c|c|c|}
\hline \multirow[t]{3}{*}{ Jenis cacing } & \multicolumn{6}{|c|}{ Pengobatan } \\
\hline & \multirow{3}{*}{ Jumlah telur } & \multicolumn{2}{|c|}{ Sebelum } & \multicolumn{3}{|c|}{ Sesudah } \\
\hline & & Epg & $\begin{array}{c}\text { Intensitas } \\
\text { infeksi }\end{array}$ & $\begin{array}{c}\text { Jumlah } \\
\text { telur }\end{array}$ & Epg & $\begin{array}{c}\text { Intensitas } \\
\text { infeksi }\end{array}$ \\
\hline \multicolumn{6}{|l|}{$\mathbf{A L}$} & \\
\hline $\mathrm{Sa} 2$ & 2 & 48 & Ringan & 0 & 0 & Sembuh \\
\hline $\mathrm{Sa} 4$ & 1 & 24 & Ringan & 0 & 0 & Sembuh \\
\hline $\mathrm{Sa} 6$ & 1 & 24 & Ringan & 0 & 0 & Sembuh \\
\hline \multicolumn{7}{|l|}{ TT } \\
\hline $\mathrm{Sa} 3$ & 2 & 48 & Ringan & 0 & 0 & Sembuh \\
\hline $\mathrm{Sa} 5$ & 4 & 96 & Ringan & 3 & 72 & Ringan \\
\hline P Value Wilcoxon & 0,157 & 0,38 & 0,46 & & & \\
\hline
\end{tabular}

Pemeriksaan feses menggunakan metode kato katz ditemukan telur Ascaris lumbricoides dengan total 4 butir pada 3 responden dan telur Trichuris trichiura dengan total 6 butir pada 2 responden. Setelah mengetahui jumlah telur dari setiap cacing, lalu menghitung EPG dan menentukan intesitas infeksi cacing dari setiap responden dan didapatkan hasil EPG dari setiap sampel Ascaris lumbricoides sebelum pengobatan yaitu sampel 2 sebanyak 48 sedangkan sampel 4 dan 6 sebanyak 24 dengan intensitas infeksi penyakit termasuk dalam kategori ringan. Hasil EPG dari setiap sampel Trichuris trichiura berturut-turut sebelum pengobatan yaitu sampel 3 sebanyak 48 sedangkan sampel 5 sebanyak 96 dengan intensitas infeksi penyakit termasuk dalam kategori ringan. Setelah itu, sampel dilakukan perlakuan berupa terapi
Albendazole $400 \mathrm{mg}$ dosis tunggal dan didapatkan hasil EPG dari setiap sampel Ascaris lumbricoides setelah yaitu sampel 2, 4 dan 6 tidak ditemukan lagi telur cacing dan dinyatakan sembuh sedangkan hasil EPG dari setiap sampel Trichuris trichiura berturut-turut sebelum pengobatan yaitu sampel 3 tidak ditemukan lagi telur cacing dan dinyatakan sembuh sedangkan sampel 5 sebanyak 72 dengan intensitas infeksi penyakit termasuk dalam kategori ringan. Hal ini menandakan bahwa terdapat satu responden yang masih terinfeksi cacing Trichuris trichiura setelah pemberian Albendazole $400 \mathrm{mg}$.

Didapatkan hasil bahwa p value Wilcoxon dari variable jumlah telur, EPG, dan intensitas penyakit $>0,05$ berturut-turut yaitu $0,157,0,38$ dan 0,46 yang menandakan bahwa Ho diterima di mana 
tidak terdapat perbedaan yang signifikan dan bermakna dari hasil jumlah telur sebelum dan sesudah pengobatan Albendazole dalam infeksi cacing usus.

Tabel 4. Efek Samping Pemberian Albendazol $400 \mathrm{mg}$

\begin{tabular}{ccc}
\hline Efek samping & Ya & Tidak \\
\hline Pusing & $1(16,7 \%)$ & $4(83,3 \%)$ \\
Diare & $2(33,3 \%)$ & $3(66,7 \%)$ \\
Mual & $1(16,7 \%)$ & $4(83,3 \%)$ \\
\hline
\end{tabular}

Penelitian ini menunjukkan hasil bahwa 2 dari 5 responden yang melakukan pengobatan Albendazole mengalami efek samping berupa pusing, mual dan diare dengan persentase berturutturut $16,7 \%, 33,3 \%, 16,7 \%$. Dari persentase tersebut dapat disimpulkan bahwa diare menjadi efek samping terbanyak yang dialami oleh responden.

\section{Pembahasan}

Hasil penelitian ini menunjukkan bahwa murid perempuan lebih banyak terinfeksi cacing usus dibandingkan dengan murid laki-laki. Infeksi cacing usus merupakan penyakit infeksi yang tidak dipengaruhi jenis kelamin sebagai faktor risiko. Oleh karena itu, penelitian ini mendapatkan hasil yang berbeda yang dapat disebabkan oleh pengambilan data yang berbeda dari setiap penelitian baik dari segi waktu dan tempat. Menurut penelitian yang dilakukan Faridan $\mathrm{K}$ et al pada tahun 2013, anak berjenis kelamin perempuan juga dapat banyak terinfeksi cacingan karena berkaitan dengan permainan yang sering dimainkan di tanah seperti permainan tali yang dilakukan di halaman sekolah, selain itu terinfeksi cacingan juga tergantung dari perilaku bersih. ${ }^{14}$

Data penelitian ini menunjukkan bahwa anak rentang usia 11-13 tahun yang banyak terinfeksi cacing usus. Penelitian yang dilakukan Ginting pada tahun 2008 menyatakan hal yang memengaruhi cacingan adalah meningkatnya aktivitas bermain dan mobilitas siswa pada kelompok umur 9-11 tahun sehingga risiko tertular cacing lebih besar akan tetapi secara epidemiologi menyebutkan puncak terjadinya infeksi cacingan adalah pada usia 5-10 tahun. Hal ini menunjukkan bahwa ada risiko terinfeksi cacingan lebih tinggi pada usia yang semakin rendah. ${ }^{15}$ Data WHO 2015 menyatakan bahwa terdapat lebih dari 267 juta anak-anak yang belum memasuki usia sekolah dan lebih dari 568 juta anak-anak yang memasuki usia sekolah ditularkan secara intensif melalui kontaminasi telur pada tangan dan makanan oleh cacing usus ini dan membutuhkan perawatan, intervensi. dan pencegahan. ${ }^{9}$

Penelitian ini mendapatkan bahwa anak kelas 5 SD yang banyak terinfeksi cacing usus. Kelompok kelas 5 SD berada pada kelompok rentang umur 11-13 tahun yang memiliki tingkat aktivitas yang tinggi sehingga memiliki risiko terinfeksi cacing yang lebih tinggi. ${ }^{14}$ Menurut penelitian yang dilakukan Faridan K et al pada tahun 2013, tingginya penderita cacingan pada tingkat pendidikan yang rendah ini dapat juga dikarenakan masih rendahnya tingkat pengetahuan dan kesadaran yang mereka peroleh serta kemampuan mereka dalam menerima pendidikan kesehatan. ${ }^{14}$

Penelitian ini ditemukan lebih banyak infeksi yang disebabkan oleh spesies Ascaris lumbricoides. Salah satu faktor yang memengaruhinya adalah kondisi lingkungan tempat penelitian. Berdasarkan pengamatan pada kondisi lingkungan sekitar tempat penelitian didapatkan kondisi tanah yang lembap, sehingga hal ini menguntungkan untuk infeksi dari cacing Ascaris lumbricoides, karena kondisi kelembapan tanah yang tinggi baik untuk perkembangan telur menjadi bentuk infektif. ${ }^{16}$ Indonesia merupakan negara tropis dengan prevalensi Ascaris lumbricoides sangat tinggi yaitu mencapai $70 \%{ }^{3}$ Individu yang menderita STH seringkali tidak memakai alas kaki dalam melakukan aktivitas sehari-hari, dan pada penelitian ini, anak-anak seringkali bermain dengan tanah sehinga dapat meningkatkan risiko infeksi STH. Tidak menutup kemungkinan bahwa setiap tempat atau wilayah mempunyai angka prevalensi yang berbeda dikarenakan berbagai faktor seperti faktor iklim misalnya, temperatur, kelembaban, curah hujan, dan faktor lainnya seperti tingkat pendidikan yang rendah, hygiene pribadi yang buruk, serta sosio ekonomi yang rendah. ${ }^{1}$

Pada penelitian ini gambaran infeksi cacing usus $7,3 \%$ dan setelah dilakukan pengobatan didapatkan penurunan prevalensi cacingan menjadi $1,2 \%$. Hal ini sejalan dengan penelitian yang dilakukan oleh Annisa et al pada tahun 2017 yang menyatakan bahwa prevalensi STH sebelum pengobatan Albendazole $400 \mathrm{mg}$ dosis tunggal 89,6\% dengan rincian Ascaris lumbricoides (77,6\%) menjadi (24,2\%) dengan CR 90,9\% sedangkan Trichuris trichiura (67,2\%) mengalami peningkatan menjadi $(89,4 \%)$ dengan CR 33,8\%. ${ }^{17}$ Hal ini sejalan juga dengan penelitan yang dilakukan oleh Legese et al pada tahun 2002, menyatakan bahwa obat Albendazole dosis tunggal sangat efektif terhadap infeksi Ascaris lumbricoides, dengan CR lebih dari 96\% dan ERR lebih dari 99,8\%, sedangkan efektivitas obat 
terhadap infeksi Trichuris trichiura rendah yang menunjukkan CR dan ERR masing-masing 13,9\% dan $63,4 \% .{ }^{8}$ Efektivitas obat Albendazole dosis tunggal kurang efektif untuk mengobati Trichuris trichiura. Hal ini sejalan dengan penelitian yang dilakukan Annisa et al pada tahun 2017 dan penelitian yang dilakukan Wahdini et al pada tahun 2018 yang menyebutkan bahwa albendazol memiliki efektivitas lebih tinggi untuk mengobati Ascaris lumbricoides dan cacing tambang dibandingkan dengan Trichuris trichiura. ${ }^{17,18} \mathrm{Hal}$ ini mungkin disebabkan oleh karena pemberian satu kali dosis tunggal Albendazole tidak cukup kuat untuk mengeliminasi Trichuris Trichiura atau kemungkinan telah terjadi resistensi obat Albendazole. ${ }^{19}$ Apabila dosis Albendazole $400 \mathrm{mg}$ untuk mengobati Trichuris trichiura dapat diberikan selama 3 hari, maka akan memberikan $\mathrm{CR}$ yang lebih baik daripada pemberian dosis tunggal, karena dosis yang berturut-turut akan memperpanjang waktu kontak obat dengan cacing, sehingga efektivitas obat menjadi meningkat. ${ }^{20}$ Selain itu juga penyerapan absorbsi obat Albendazole akan meningkat jika diberikan dengan makanan yang berlemak, seperti susu atau biskuit susu untuk meningkatkan absorbsi. ${ }^{18,11}$

Hasil uji Mc Nemar pada penelitian ini tidak terdapat perubahan yang signifikan dan bermakna dari hasil sebelum dan sesudah pengobatan Albendazole $400 \mathrm{mg}$ dosis tunggal dalam infeksi cacing usus. Hal ini berbeda dengan penelitian Sri Wahdini, Yusuf A. Fikri, Saleha Sungkar pada tahun 2018, bahwa terdapat perbedaan yang bermakna antara sebelum dan sesudah dilakukan pengobatan. ${ }^{18} \mathrm{Hal}$ ini dapat disebabkan karena sedikitnya jumlah sampel yang positif, distribusi data yang tidak normal, dan juga intensitas infeksi rendah sehingga pengobatan yang dilakukan tidak terdapat perubahan yang signifikan dan bermakna secara statistik.

Intensitas derajat infeksi pada penelitian ini yang terinfeksi Ascaris lumbricoides maupun Trichuris trichiura keduanya termasuk derajat infeksi ringan. Hasil uji Wilcoxon pada penelitian ini tidak terdapat perbedaan yang signifikan dan bermakna dari hasil jumlah telur sebelum dan sesudah pengobatan Albendazole dalam infeksi cacing usus. Hal ini dapat disebabkan oleh sedikitnya jumlah sampel yang positif, intensitas infeksi rendah dan hal ini dibuktikan dengan distribusi data yang tidak normal.

Penelitian ini menunjukkan bahwa diare menjadi efek samping terbanyak yang dialami oleh responden. Hal ini sejalan dengan penelitian lain yang dilakukan oleh Julianto pada tahun 2017 yang menyatakan bahwa 8 dari 60 sampel mengalami efek samping berupa mual dan diare setelah pemberian Albendazole. ${ }^{21} \mathrm{Hal}$ ini berbeda dengan penelitian Yunus $\mathrm{R}$ pada tahun 2008 yang menyatakan bahwa 2 dari 67 sampel mengalami efek samping sakit kepala setelah pemberian Albendazole. ${ }^{22}$ Oleh karena itu, penelitian saya mendapatkan hasil yang berbeda dengan penelitian lain dan tidak signifikan mengalami efek samping yang sama. Jadi tidak ada efek samping yang berat setelah pemberian Albendazole pada penelitian ini dan biasanya efek samping tersebut akan sembuh dengan sendirinya.

\section{Simpulan}

Siswa yang terinfeksi cacing usus di Sekolah Dasar Negeri Cilincing 06 Jakarta Utara lebih banyak yang berjenis kelamin perempuan dengan rentang usia 5-11 tahun dan duduk dikelas 5. Kejadian infeksi cacing usus sebelum pemberian pengobatan adalah 6,1\% dengan rincian Ascaris lumbricoides $3,7 \%$, Trichuris trichiura $2,4 \%$. Sesudah pemberian pengobatan albendazole 400 mg dosis tunggal, Kejadian infeksi cacing usus terjadi penurunan menjadi $1,2 \%$ dengan rincian Ascaris lumbricoides 0\% sedangkan Trichuris trichiura $1,2 \%$. Hasil penelitian ini menunjukkan bahwa secara statistik tidak terdapat perbedaan yang bermakna pada infeksi cacing usus sebelum dan sesudah pengobatan albendazole dosis tunggal. Albendazole $400 \mathrm{mg}$ dosis tunggal efektif terhadap Ascaris lumbricoides dan kurang efektif terhadap Trichuris trichiura walaupun dengan derajat infeksi yang ringan. Dijumpai efek samping obat terbanyak berupa diare dan akan sembuh dengan sendirinya.

\section{Daftar Pustaka}

1. Palgunadi BU. Faktor-faktor yang memengaruhi kejadian kecacingan yang disebabkan oleh soil-transmitted helminthes di Indonesia. Acad Jurnalis. 2016;6(8):11723.

2. Mulle I, Yap P, Steinmann P, et al. Intestinal parasites, growth and physical fitness of schoolchildren in poor neighbourhoods of Port Elizabeth, South Africa: a cross-sectional survey. BioMed Central. 2016;9:488.

3. Darnely, Sungkar S. Infeksi parasit usus pada anak panti asuhan di Pondok Gede Bekasi. J Indon Med Assoc. 2011;61(9):347-51

4. Hadidjaja P, Margono SS. Dasar parasitologi klinik. Jakarta: Fakultas Kedokteran Universitas Indonesia; 2011.h.121-63.

5. WHO. Soil-transmitted helminthes infection. 2015. [cited 5 Nov 2018]. Available from: 
http://www.who.int/mediacentre/factsheets/f s366/en/.

6. Tangel F, Tuda JSB, Pijoh VD. Infeksi parasit usus pada anak sekolah dasar di pesisir pantai Kecamatan Wori Kabupaten Minahasa Utara. J e-Biomedik (eBm). 2016;(1):4.

7. Soedarto. Pengobatan penyakit parasit. Surabaya:Sagung Seto; 2009.h.138-44.

8. Legese M, Erko B, Medhin G. Efficacy of albendazole and mebendazole in the treatment of Ascaris and Trichuris infection. Ethiop Med J. 2002;40:335-43.

9. Mardiana., Djarismawati. Prevalensi cacing usus pada murid sekolah dasar wajib belajar pelayanan terpadu, pengentasan kemiskinan daerah kumuh di wilayah DKI Jakarta. J Ekologi Kesehatan. 2008;2(7):769-74.

10. Sastroasmoro S, Ismael S. Dasar-dasar metodologi penelitian klinis. Edisi ke-5. Jakarta: Sagung Seto; 2014.

11. Adugna S, Kebede T, Mekonnen Z, dkk. Diagnostic performance of mini parasep solvent-free faecal parasite concentrator relative to Kato-Katz and McMaster for the diagnosis of intestinal parasitic infections. Transaction of the Royal Society of Tropical Medicine and Hygine. 2018;111(12):1-7

12. Sari MP, Supali T, Wibowo H. Perbandingan uji diagnostik mini flotac dengan Kato Katz sebelum dan sesudah pengobatan Albendazol dosis tunggal pada anak yang terinfeksi cacing usus. Jurnal Kedokteran Meditek. 2015;21(55):1-7.

13. Ilahude HD, Sjarifuddin PK, Djakaria S. Penuntun praktikum parasitologi kedokteran. Jakarta: Penerbit FK UI, Jakarta. 2010. h.289.

14. Faridan K, Marlinae L, Audhah NA. Faktorfaktor yang berhubungan dengan kejadian kecacingan pada siswa Sekolah Dasar Negeri Cempaka 1 Kota Banjarbaru. Jurnal Buski. 2013;4(3).

15. Ginting A. Faktor-faktor yang berhubungan dengan kejadian kecacingan pada anak sekolah dasar di desa tertinggal Kecamatan Pangukuran Kabupaten Samosir. Medan: Universitas Sumatera Utara; 2008. Skripsi.

16. Sutanto I, Ismid IS, Sjarifuddin PK, Sungkar S. Buku ajar parasitologi kedokteran. Edisi 4. Jakarta: FK UI; 2008.

17. Annisa I, Damayanti R, Trianto DM, Wiratama MP, Wahdini S, Sungkar S. Pengaruh pengobatan Albendazol dosis tunggal terhadap infeksi soil-transmitted helminthes dan status gizi anak Desa Perokonda, Sumba Barat Daya. Fakultas
Kedokteran Universitas Indonesia; eJKI, 2017;5(2):114-20.

18. Wahdini S, Fikri YA, Sungkar S. Efektivitas mebendazol double-dose terhadap infeksi soil-transmitted helminthes di Desa Perokonda, Sumba Barat Daya. Fakultas Kedokteran Universitas Indonesia; eJKI, 2018;6(2):128-32.

19. Dharma YP. Resistensi anti helminth pada infeksi soil transmitted helminth. Fakultas Kedokteran Universitas Lampung; J Agromed Unila. 2015;2(2):161-4.

20. Sungkar S, Putri KQ, Taufik MIS, Gozali MN, Sudarmono P. The effectiveness of triple dose Albendazole in treating soil transmitted helminths infection. Fakultas Kedokteran Universitas Indonesia; Journal of Parasitologi Research. 2019;19(6438497):1-4.

21. Julianto E. Perbandingan efikasi dan efek samping antara albendazole, albendazolelevamisol dan mebendazol-levamisol terhadap infeksi soil-transmitted helminthes pada anak usia sekolah dasar negeri Kabupaten Deli Serdang Medan. Jurnal Ilmu Kefarmasian Indonesia, 2017;15(2):167-73.

22. Yunus R. Keefektifan Albendazole pemberian sekali sehari selama 1, 2 dan 3 hari dalam menanggulangi infeksi Trichuris trichiura pada anak sekolah dasar di Kecamatan Medan Tembung. Medan: Universitas Sumatera Utara; 2008. Skripsi. 